\title{
Students' Committing Plagiarism and Reading Habit: Exploring Possible Relationship
}

\author{
Mohamad Salik \\ English Language Education Department, \\ UIN Sunan Ampel Surabaya \\ Nadiya Dwiki Isnin Safitri \\ English Language Education Department, \\ UIN Sunan Ampel Surabaya
}

\begin{abstract}
The inevitable rise of plagiarism is still being a continuous issue, particularly among university students. Plagiarism does have a bunch of causes and factors to be hindered. One possible aspect that considers as the cause of plagiarism is reading habit, by realizing the fact that reading has a strong inseparable link towards writing skill. However, the role of reading habit in plagiarism's cause has not been examined by the previous studies and that leads this study to examine the correlation between students' reading habits and their committing plagiarism. This study was performed with a quantitative research method, the sample of this study is 33 students of Research Proposal Seminar B-class in the sixth semester of English Teacher Education Department of UIN Sunan Ampel Surabaya. The results reveal that each category of reading habit includes reading attitude, reading motivation, belief in reading, reading purpose, and reading preference show different correlations result with plagiarism percentage. Several of them indicate having no correlation with the plagiarism percentage and the others indicate having slightly correlation, but overall categories reveal having no significant correlation at all with plagiarism. Knowing this fact, it can be said that reading habit has a low correlation in committing plagiarism.
\end{abstract}

\section{Keywords: plagiarism, reading habit, students}

\section{INTRODUCTION}

Over the last decade plagiarism has increasingly been becoming a major issues that defeat education aims. Plagiarism is the act of incorporating another person's work, ideas or words into the writer's work in large chunks, beyond what is considered to be general knowledge. The writer then claims the text to be his / hers without attributing the text to its original source (Pecorari, 2008). Plagiarism may impede student success since it is known as academic theft,

\author{
Talitha Rizky Satyaputri \\ English Language Education Department, \\ UIN Sunan Ampel Surabaya \\ Nurmaya Ningsih \\ English Language Education Department, \\ UIN Sunan Ampel Surabaya
}

academic dishonesty and academic misconduct in education sector, so it possibly incurs penalties when it is revealed. Although students are aware of its potential consequences, plagiarism continues.

This academic dishonesty happens for various reasons and one of them is the unstoppable technology and internet evolution that make students feel free and easy todownload internet sources.Theflood of online resources, without precisely stating authorship, may become one of the problems where students have difficultyin determining what is right and what is wrong(Kokkinaki, Demoliou, \& Iakovidou, 2015). Onlineresources are also available 24 hours a day, 7 days a weekend enable a bunch of information, which more broaden the students' chance to copy paste as the shortcut of their work.Other researchers (Pecorari, 2008; Rinnert \& Kobayashi, 2005) have the idea that difficulties of a second language authors, are probably the lack of an adequate command of the language, which can cause insecurity about their use of language and therefore make depend too much on the original texts. Thereforethey tend to plagiarize others' work that provide in the internet as the the quickest solution to tasks, regardless of the validity of the sources or without respecting the work of others (Sureda, Comas and Oliver, 2015). Several researchers have noted that students maybe more likely to ignore academic ethics in utilizing the online sources(ChangChen, Huang, \& Chou, 2015).Digital source are seen asdouble edge sword because, it provides material for students to support their writing and this alsofacilitates the academic plagiarism among students (Robert, 2008).

Another influential factor of plagiarism is the lack of writing skill.Some studies conveyed that an individual who has adequate competence in writing, they tend to not commit plagiarism(ApatsaSelemani, 2018; Shi ChiehChien, 2014; and Lucy R Betts 2012). Poor writing, paraphrasing, and referencing skills are common and easily identifiable reasons of misappropriation of others' intellectual property, warranting advanced academic (Armen Yuri, 2017). Student writers face 
various writing problems at different stages of their writing learning learning. Sajid Muhammad (2016) classify the writing as a poor writing because of the deficiencies in use of tenses, ambiguous or loose sentence construction, unparallel sentence construction, flaws in surface and deep structuresentences, poor diction (vocabulary) and expression (style of language), lack of transforming or paraphrasing texts for synthesizing information, poor grammatical knowledge, and errors in use of pronouns, articles, punctuations etc.Majority of the students find it very challenging to obtain sufficient and relevant source information, paraphrase or summarise information, and use an appropriate academic writing style (Gonye, Mareva, Dudu, \& Sib, 2012; Kalikokha, 2008).Those insufficient linguistic proficiency in writing can lead the students into a bad deed in academic sector such as plagiarism (Farid muhammad, 2016).

To hinder from poor writing that can be potentially called as plagiarism, students should own the ability of good writing and it will result them to be a good writer. Commonly, a good writer is the one who are widely knowledgeable, have a good vocabulary mastery, the ability to construct the idea quickly, and the ability to apply writing skills. One powerful factor that can lead students to be a good writer without entangled with plagiarism is having a good reading habit. In habitual reading students can gain a meaningful knowledge and boost their vocabulary mastery. Students can learn a new word and introduce to new facts that makes them confident in writing(Thanuskodi, 2011).Steel jack (2008) also mentions by a good reading habit students become knowledgeable of many kinds of insights that support them to think critically. Another study comes from Myarta (2016) states that there is significance correlation between reading and grammar.

Which means, how good the reading habit of students can determine their grammatical comprehension. Those obtaining the choices of wordsand grammatical knowledge can be the preventive effort of plagiarism. For instance students can utilize the new choices of words for paraphrasingand summarizing the passage. Additionally the knowledge or idea from reading combine with critical thinking can enable students to write quickly and well-read. Students also will get familiar with citation and quoting from the journals or articles that they read. If students own every mentioned aspects that obtained from reading habit above they will not get involved with plagiarism, because they have already had adequate knowledge and confidence to write.Furthermore, the study from Eva Jereb (2017) strengthened that assumption, one of the factor of students' committing plagiarism is lack of reading comprehension. So plagiarism logically can be prevented by good reading habit.
From the theories above, it can be summed up that plagiarismhas possibly link with reading skill, since reading and writing are also the two inseparable language skills. There are a million of studies out there, which concern about the relationship between plagiarism and writing skill, and the proofs showed that they are linked each other. But none of them are focus on the reading skill that actually known as the main skill for writing source and can be the preventive action of committing plagiarism. Based on above mentioned rationale, this present research provides the newest contribution by going deeper focusing on whether committing plagiarism and reading habit have a significance correlation or not. Not to mention researcher will convey the average percentage of students plagiarism and the average of students' reading habit score.

This study was mainly based on quantitativedesign that involved 30 students of research proposal seminarin the sixth semester of English Teacher Education Department of UIN Sunan Ampel Surabaya chosen by simple random sampling technique. The data of reading habit were collected through questionnaire with 42 items adapted by researchers from similar research. This study also use an application called Turnitinto obtain the data of plagiarism from the introduction part of the 30 students'proposal.

From the background of research above we are able to find some problems that are related to the student's committing plagiarism and reading habit. The researchers try to identify the problems into some questions:

1. What is the average of plagiarism percentage among students Research Proposal Seminar class B sixth semester?

2. What is the average of students' reading habit score among students Research Proposal Seminar class B sixth semester?

3. What is the correlation of students committing plagiarism with students reading habit?

This research hypothesis is: There is a significant effect of reading habit towards students' committing plagiarism. Hopefully, these findings can be used as a basis for improving students' ability to apply reading habits for students to minimize or eliminate the existence of plagiarism in writing English according to the level of education.

\section{METHOD}

\section{A. Variable of the Research}

In this research, the researchers used two variable consist of the percentage of plagiarism among students of research proposal seminar class and students'reading habits.

B. Sample and Populationof the Research 
The population taken in this study was all of students of research proposal seminar class in the sixth semester of English Teacher Education Department of UIN Sunan Ampel Surabaya. The total numbers of the students are about 125 students in 4 different classes. The sample taken was $25 \%$ from the populationbecause if the population is more than 100 the researcher should take the sample between $10 \%-15 \%$ or $20 \%-25 \%$ or more (Arikunto 2006:71). The writer applied simple random sampling technique in taking the sample. Among 4 classes, the researchers got B class of research proposal seminar containing 33 students.

\section{Limitation of the Research}

There are several plagiarism detection system availale, such as plagiarism checker, Unicheck, DupliChecker, Turnitin, etc. But the researchers only use the application of turnitin to detect students' plagiarism percentage. The turnitin application cannot check all possible kinds of plagiarism, only some kinds of plagiarism that can be detected.

\section{Research Instrument}

The instruments which were used in this study were aimed to measure the students' reading habit and students' plagiarism percentage. Students' reading habit was measured through questionnaire and the application of turnitin was used to measure students' plagiarism percentage. The researchers used the online form in administering reading habit questionnaire.

\section{a. Questionnaire}

The questionnaire for measuring the readingdistributed to students of Research Proposal Seminar B class by the researchers through Google Form Link. Using a reading habit questionnaire that was developed by the researcher and validated by experts. The questionnaire with 42 items adapted by researches from similar research, consists of multiple choice as the likert scale (strongly agree, agree, neutral, disagree, and strongly disagree).The categories of the questionnaire include students' reading attitude, reading frequency, reading belief, reading purpose, and reading preference.

\section{b. Using application}

The Turnitin application was a well known tool that used to check the plagiarism in the writing test of the student. The researchers asked the students to collect their introduction of Research Seminar Proposal, then the researchersanalyzed the result and the correlation with their reading habit.

\section{E. Procedure Data Collection}

The procedures of collecting the data of this research involved several steps. The first was constructing questionnaire to measure students' reading habit about reading habit to 33 students of sixth semester English education department of UIN
SunanAmpelSurabaya.The questionnaire provided personal information to be filled by the correspondents such as name and gender to assist the researcher knowing the identity of students. Additionally, the questionnaire included students' reading attitude, reading frequency, reading belief, reading purpose, and reading preference. The next step was from the same 33 students, data of plagiarism were collected by checking their proposal research introduction using application named turnitin. Turnitinisa well-known plagiarism application checker to find the plagiarism percentage of each student. The last step was the data from turnitin Application will be analyzed to measure the validity and reliabilityand obtained into SPSS program.

\section{F. Data Analysis}

After obtaining the data of students reading habit questionnaire result and plagiarism percentage the data will be analyzed by using SPSS program.

With SPSS program, the researcher got the $r$ coefficient (Pearson Correlation) that can describe the correlation between $\mathrm{X}$ variable and $\mathrm{Y}$ variable, as below:

Significance score $<0.05$ means there is a correlation

Significance score $>0.05$ means there is no correlation

\begin{tabular}{|c|l|}
\hline \multicolumn{1}{|c|}{$\begin{array}{c}\text { Size of } \\
\text { Correlation }\end{array}$} & \multicolumn{1}{|c|}{ Interpretation } \\
\hline $0,00-0.20$ & $\begin{array}{l}\text { The correlation between } \\
\mathrm{X} \text { variable and Y variable } \\
\text { is very weak or can be say } \\
\text { there is no correlation } \\
\text { between the variables. }\end{array}$ \\
\hline $0,21-0,40$ & $\begin{array}{l}\text { The correlation between } \\
\mathrm{X} \text { variable and Y variable } \\
\text { is weak. }\end{array}$ \\
\hline $0,41-0,60$ & $\begin{array}{l}\text { The correlation between } \\
\mathrm{X} \text { variable and } \mathrm{Y} \text { variable } \\
\text { is medium. }\end{array}$ \\
\hline $0,61-0,80$ & $\begin{array}{l}\text { The correlation between } \\
\mathrm{X} \text { variable and } \mathrm{Y} \text { variable } \\
\text { is strong. }\end{array}$ \\
\hline $0,81-1,00$ & $\begin{array}{l}\text { The correlation between } \\
\mathrm{X} \text { variable and Y variable } \\
\text { is perfect. }\end{array}$ \\
\hline
\end{tabular}




\section{FINDINGS AND DISCUSSION}

\section{Findings}

In this study the researchers do correlation test for reading habit and plagiarism, but before that researchers calculate the mean from both reading habit and plagiarism first.

1. The Mean of Reading Habit

The researchers calculate the mean of reading habit that have the criteria of score as follow:

- Low : $<60$

- Standard: $61-79$

- High : 80-90 Table 4.1 Mean of Reading Habit

Statistics

TOTALALL

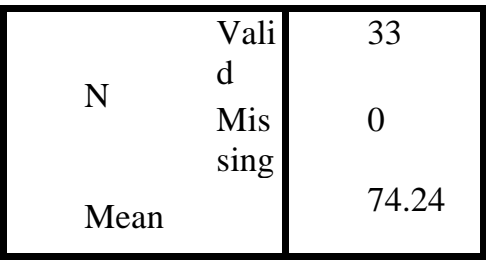

Table 4.2 Reading Habit Score

TOTALALL

\begin{tabular}{|c|c|c|c|c|c|}
\hline & $\begin{array}{c}\text { Frequenc } \\
y\end{array}$ & $\begin{array}{c}\text { Perce } \\
\text { nt }\end{array}$ & $\begin{array}{c}\text { Valid } \\
\text { Percent }\end{array}$ & $\begin{array}{c}\text { Cumulati } \\
\text { ve } \\
\text { Percent }\end{array}$ \\
\hline \multirow{22}{*}{$\begin{array}{l}\text { Val } \\
\text { id }\end{array}$} & 57 & 1 & 3.0 & 3.0 & 3.0 \\
\hline & 62 & 1 & 3.0 & 3.0 & 6.1 \\
\hline & 64 & 1 & 3.0 & 3.0 & 9.1 \\
\hline & 65 & 2 & 6.1 & 6.1 & 15.2 \\
\hline & 66 & 1 & 3.0 & 3.0 & 18.2 \\
\hline & 67 & 1 & 3.0 & 3.0 & 21.2 \\
\hline & 68 & 2 & 6.1 & 6.1 & 27.3 \\
\hline & 69 & 2 & 6.1 & 6.1 & 33.3 \\
\hline & 70 & 1 & 3.0 & 3.0 & 36.4 \\
\hline & 71 & 2 & 6.1 & 6.1 & 42.4 \\
\hline & 72 & 1 & 3.0 & 3.0 & 45.5 \\
\hline & 75 & 3 & 9.1 & 9.1 & 54.5 \\
\hline & 76 & 3 & 9.1 & 9.1 & 63.6 \\
\hline & 77 & 1 & 3.0 & 3.0 & 66.7 \\
\hline & 78 & 1 & 3.0 & 3.0 & 69.7 \\
\hline & 80 & 1 & 3.0 & 3.0 & 72.7 \\
\hline & 81 & 2 & 6.1 & 6.1 & 78.8 \\
\hline & 83 & 2 & 6.1 & 6.1 & 84.8 \\
\hline & 84 & 1 & 3.0 & 3.0 & 87.9 \\
\hline & 85 & 1 & 3.0 & 3.0 & 90.9 \\
\hline & 86 & 2 & 6.1 & 6.1 & 97.0 \\
\hline & 89 & 1 & 3.0 & 3.0 & 100.0 \\
\hline
\end{tabular}

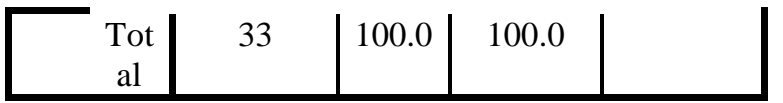

The table 4.1 above depicts the average/mean of reading habit from 33 students of Research Proposal Seminar A Class is 74.24. Which means, it belong to the standard level. From table 4.2, we know that the highest score is 89 while the lowest is 57. The majority of the score is around $60-85$ which can be belong to the standard and high level of reading habit score. There are ten correspondents who pass the high level of reading habit.

\section{Mean of Plagiarism Percentage}

Researchers calculate the mean of Plagiarism Percentage from the essay of 33 students' research seminar proposal class A. The criteria is:

- Good : $0-29 \%$

- Acceptable : 30-60\%

- Poor : > $61 \%$

Table 4.3 Mean of Plagiarism Percentege

Statistics

PLAG

\begin{tabular}{|cc|c|}
\hline \multirow{2}{*}{$\mathrm{N}$} & Valid & 33 \\
& Missing & 0 \\
& Mean & 29.73 \\
\hline
\end{tabular}


PLAG

\begin{tabular}{|c|c|c|c|c|c|}
\hline & $\begin{array}{c}\text { Frequen } \\
\text { cy }\end{array}$ & $\begin{array}{c}\text { Perce } \\
\mathrm{nt}\end{array}$ & $\begin{array}{c}\text { Valid } \\
\text { Percent }\end{array}$ & $\begin{array}{l}\text { Cumulativ } \\
\text { e Percent } \\
\end{array}$ \\
\hline \multirow{26}{*}{$\begin{array}{c}\text { Vali } \\
\text { d }\end{array}$} & 0 & 2 & 6.1 & 6.1 & 6.1 \\
\hline & 2 & 3 & 9.1 & 9.1 & 15.2 \\
\hline & 5 & 1 & 3.0 & 3.0 & 18.2 \\
\hline & 8 & 2 & 6.1 & 6.1 & 24.2 \\
\hline & 10 & 3 & 9.1 & 9.1 & 33.3 \\
\hline & 13 & 1 & 3.0 & 3.0 & 36.4 \\
\hline & 14 & 1 & 3.0 & 3.0 & 39.4 \\
\hline & 18 & 1 & 3.0 & 3.0 & 42.4 \\
\hline & 20 & 1 & 3.0 & 3.0 & 45.5 \\
\hline & 22 & 1 & 3.0 & 3.0 & 48.5 \\
\hline & 24 & 1 & 3.0 & 3.0 & 51.5 \\
\hline & 33 & 3 & 9.1 & 9.1 & 60.6 \\
\hline & 36 & 1 & 3.0 & 3.0 & 63.6 \\
\hline & 37 & 1 & 3.0 & 3.0 & 66.7 \\
\hline & 41 & 1 & 3.0 & 3.0 & 69.7 \\
\hline & 42 & 1 & 3.0 & 3.0 & 72.7 \\
\hline & 43 & 1 & 3.0 & 3.0 & 75.8 \\
\hline & 45 & 1 & 3.0 & 3.0 & 78.8 \\
\hline & 47 & 1 & 3.0 & 3.0 & 81.8 \\
\hline & 54 & 1 & 3.0 & 3.0 & 84.8 \\
\hline & 66 & 1 & 3.0 & 3.0 & 87.9 \\
\hline & 67 & 1 & 3.0 & 3.0 & 90.9 \\
\hline & 71 & 1 & 3.0 & 3.0 & 93.9 \\
\hline & 78 & 1 & 3.0 & 3.0 & 97.0 \\
\hline & 87 & 1 & 3.0 & 3.0 & 100.0 \\
\hline & Tota & 33 & 100.0 & 100.0 & \\
\hline & 1 & & & & \\
\hline
\end{tabular}

The table 4.3 shows that the average of plagiarism percentage among students written English class A is $29.73 \%$. It belongs to "acceptable" level of plagiarism. And the highest is $87 \%$ which belong to the "poor" level of plagiarism.

3.

Correlation of Plagiarism Percentage and Reading Habit Score

The criteria for the correlation and the significance are:

- $\quad$ Significance score $<0,05$ means there is a correlation

- $\quad$ Significance score $>0,05$ means there is no correlation

- $\quad$ Pearson Correlation Score 0,00 $0.20=$ no correlation
- $\quad$ Pearson Correlation Score 0,21 $0,40=$ weak correlation

- $\quad$ Pearson Correlation Score 0,41 $0,60=$ medium correlation

- $\quad$ Pearson Correlation Score 0.61 $0,80=$ strong correlation

Pearson Correlation Score 0,81-1,00 = perfect correlation

Table 4.5 Correlationof Students' Reading Attitude and Plagiarism

\section{Correlations}

\begin{tabular}{|ll|l|l|}
\hline & & $\begin{array}{l}\text { TOTALAT } \\
\text { TID }\end{array}$ & $\begin{array}{l}\text { PLA } \\
\text { G }\end{array}$ \\
\hline TOTALA & Correlation & & .088 \\
TTID & Sig. (2-tailed) & & \\
& N & .624 \\
& Pearson & .088 & 33 \\
& Correlation & & 1 \\
PLAG & Sig. (2-tailed) & .624 & \\
& N & 33 & 33 \\
\hline
\end{tabular}

Table above shows that the significance score of the correlation ofstudents' reading attitude and plagiarism percentage is 0.624 which means there is no correlation. And the Pearson correlation score is 0.088 which also means no correlation.

Table 4.6 Correlations of Students' Reading Motivation and Plagiarism

\begin{tabular}{|l|l|l|}
\hline \multicolumn{3}{|c|}{ Correlations } \\
\hline Pearson & PLAG & P16 \\
Correlation & 1 & -.038 \\
Sig. (2-tailed) & & \\
N & 33 & 33 \\
Pearson & -.038 & 1 \\
Correlation & & \\
Sig. (2-tailed) & .832 & \\
N & 33 & 33 \\
\hline
\end{tabular}

Table below shows that the significance score of the correlation ofstudents reading motivation score and plagiarism percentage is 0.832 which means there is strong negative correlation. And the Pearson correlation score is -0.038 . 
Table 4.7 Correlations of Students' Belief in Reading and Plagiarism

\begin{tabular}{|ll|l|l|}
\hline \multicolumn{5}{|c|}{ Correlations } & $\begin{array}{l}\text { TOTALB } \\
\text { EL }\end{array}$ & PLAG \\
\hline \multirow{3}{*}{ TOTALB } & $\begin{array}{l}\text { Pearson } \\
\text { Correlation }\end{array}$ & 1 & -.172 \\
EL & Sig. (2-tailed) & & \\
& N & 33 & .337 \\
& Pearson & -.172 & 1 \\
& Correlation & & \\
PLAG & Sig. (2-tailed) & .337 & \\
& N & 33 & 33 \\
\hline
\end{tabular}

Table above shows that the significance score of the correlation of students' belief in reading score and plagiarism percentage is 0.337 which means there is strong negative correlation. And the Pearson correlation score is -0.172 .

Table 4.8 Correlation of Students' Purpose of Reading and Plagiarsm

\begin{tabular}{|ll|l|l|}
\hline \multicolumn{5}{|c|}{ Correlations } & TOTALP & PLA \\
& & UR & G \\
\hline \multirow{4}{*}{ TOTALP } & Correlation & 1 & .332 \\
UR & Sig. (2-tailed) & & \\
& N & 33 & 33 \\
& Pearson & .332 & 1 \\
PLAG & Correlation & & \\
& Sig. (2-tailed) & .059 & \\
& N & 33 & 33 \\
\hline
\end{tabular}

Table below shows that the significance score of the correlation ofstudents' purpose of reading and plagiarism percentage is 0.059 which means there is no correlation. And the Pearson correlation score is 0.332 which also means no correlation.

Table 4.9 Correlationof Students' Reading

Preference and Plagiarism

\section{Correlations}

\begin{tabular}{|ll|l|l|}
\hline & & $\begin{array}{l}\text { TOTALP } \\
\text { REF }\end{array}$ & $\begin{array}{l}\text { PLA } \\
\text { G }\end{array}$ \\
\hline TOTALP & Correlation & 1 & -.123 \\
REF & Sig. (2-tailed) & & \\
& N & .43 & 33 \\
& Pearson & -.123 & 1 \\
& Correlation & & \\
PLAG & Sig. (2-tailed) & .496 & \\
& N & 33 & 33 \\
\hline
\end{tabular}

Table below shows that the significance score of the correlation ofstudents' reading preference score and plagiarism percentage is 0.496 which means there is strong negative correlation. And the Pearson correlation score is -0.123 .

Table 4.10 Correlation All Categories of Reading Habit and Plagiarism

\begin{tabular}{|ll|l|l|}
\hline \multicolumn{5}{c|}{ Correlations } \\
\hline \multirow{4}{*}{ TOTALA } & $\begin{array}{l}\text { TOTAL } \\
\text { ALL }\end{array}$ & $\begin{array}{l}\text { PLA } \\
\text { G }\end{array}$ \\
LL & Searson Correlation & 1 & .001 \\
& N & & .998 \\
& Pearson Correlation & .001 & 1 \\
PLAG & Sig. (2-tailed) & .998 & \\
& N & 33 & 33 \\
\hline
\end{tabular}

Table below shows that the significance score of the correlation oftotal reading habit score and plagiarism percentage is 0.998 which means there is no correlation. And the Pearson correlation score is 0.001 which also means no correlation.

\section{Discussion}

Do students with a good reading habit will not commit plagiarism? Or are students who commit much plagiarism are those who have a bad reading habit? The present study examined this issues, by determining whether or not reading habit correlates with students' committing plagiarism. By having hypothesis that a student who has a good reading habit will not commit plagiarism, this study collected the data through 19 valid items of reading habit questionnaire.

First of all, regarding with the average of students' reading habit score and plagiarism 
percentage, table 4.1 and 4.2 shows that the average of students' reading habit score is 74,24. From table 4.2 , it can be seen that there is no significance difference between one student's reading habit score with others students. With the majority score around $60-85$, it can be concluded that students' reading habit score is on the standard and high level which means great because the majority of them have a quite good habit in reading.

Meanwhile table 4.3 depicts the average score of students' plagiarism percentage is on the low level which is $29.73 \%$. Almost all students' plagiarism percentage are in the acceptable and low level. It means that they are all aware about plagiarism even though several of them still have more than $60 \%$ of plagiarism percentage.

For the correlation between reading habit and plagiarism, researchers did not merely measure the overall reading habit but measured of each category of reading habit, includes reading attitude, reading motivation, belief in reading, reading purpose, and reading preference.

Basically the findings show the opposite way from the hypothesis. From table 4.5 , it can be seen that there is no correlation between students' reading attitude and their plagiarism. But this result is supported by the study from Graham (2012), found that reading attitude cannot predict the writing performance. Meanwhile for category reading motivation, the finding conveys that there is a very slightly possible correlation with the plagiarism percentage. Because the Pearson correlation shows negative score which is -. 038. It means that the higher students' motivation in reading also the less the plagiarism percentage is. But the thing is the possibility is too weak. So do with the categories of students' belief in reading and students' reading preferences, that have Pearson correlation -.172 and -.123 , means that the better their belief of reading and reading preferences is, the less they commit plagiarism. But still, the correlation is not adequate enough.

On the other hand, in the category of reading purpose do not show any correlation at all with the plagiarism percentage. Which the Pearson correlation is 0.332 consider as the very weak correlation and the significance score is 0.59 means no significance correlation. So it means that students' reading purpose does not influence their writing performance that can be linked with committing plagiarism.

Lastly, table 4.10 depicts that there is no correlation between overall reading habit and the plagiarism percentage. It can be seen that the Parson correlation is 0,001 means exceptionally weak and the significance score is 0,998 and it is obviously not significance. In contrast with Eva Jereb (2017)' study that found lack of reading comprehension can cause students commit plagiarism.

\section{CONCLUSION}

In short. based on the findings and discussion there is no significant correlation between students' reading habit and plagiarism. For several categories, some of them still have very slight correlation for instance the reading purpose category but some of them also have no correlation at all such as the reading attitude. To sum up this study did not find any strong correlation both from overall reading habit or each category of reading habit with the students' plagiarism percentage.

\section{REFERENCES}

[1] Alqadi, K., \& Alkadi, M. (2013). The effect of extensive reading on developing the grammatical accuracy of the EFL freshmen at Al Al-Bayt University. Journal of Education and Practice, 4(6), 106-113

[2] Chang CM, Chen YL, Huang Y, Chou C. Why do they become potential cyber-plagiarizers? Exploringthe alternative thinking of copy-and-paste youth in Taiwan. Computers and Education. 2015; 87: 357 367 .

[3] Ehrich, J., Howard, S. J., Mu, C. \& Bokosmaty, S. (2016). A comparison of Chinese and Australian university students' attitudestowards plagiarism. Studies in Higher Education, 41 (2), 231-246.

[4] Esmaeili, H. (2002). Integrated reading and writing tasks and ESL students' reading and writing performance in an English Language Test. Journal of Canadian Modern Language Review, 58(4), 599-620

[5] Gardner, B. 2012. Habit as Automaticity, Not Frequency, Journal of TheEuropean Health Psychologist.

[6] Hansen, B. (2003). Combating plagiarism: Is the internet causing morestudents to copy? The CQ Researcher, 13, 773-796.

[7] Ï prajc P, Urh M, Jerebic J, Trivan D, Jereb E. Reasons for plagiarism in higher education. Organizacija.2017; 50(1): $33 \pm 46$.

[8] Palani, K. K. (2012) Promising Reading Habits and Creating Literate Social. InternationalReference Research Journal Vol. III Issue 2(1) pp 91.Singh

[9] Plakans, L., \& Gebril, A. (2012). A close investigation into source use in integrated second language writing tasks. Assessing Writing, 17(1), 18-34.

[10] Park, C. (2003). In other (people's) words: plagiarism by university students -literature and lessons. Assessment \& Evaluation in Higher Education, 28(5), 471-488.

[11] Patel, M. E., Jain, P. M. (2008). English Language Teaching (Methods, Tools \& Techniques). Jaipur: Sunrise Publishers $\&$ Distributors.

[12] Ramzan M, Munir MA, Siddique N, Asif M. Awareness about plagiarism amongst university students inPakistan. High Educ. 2012; 64: 73 \pm 84 .

[13] Roberts, T.S. (2008). Student Plagiarism in an Online World. https://doi.org/10.4018/978-1-59904-801-7

[14] Tella, A., \& Akande, S. (2007). Children's reading habits and availability of books in Botswana primaryschools: Implications for achieving quality education. The Reading Matrix 7 (2) Available:http://www.readingmatrix.com/article/adeyinka/ article/pdf

[15] Thornbury, S. 2002. How to Teach Vocabulary. Edinburgh: Pearson Education Limited.

[16] Wagner, S. (2002). The reading habits of teams. Journal of Reading Today, Vol.46: 3-4. 